\title{
Description of Catellibacterium caeni sp. nov., reclassification of Rhodobacter changlensis Anil Kumar et al. 2007 as Catellibacterium changlense comb. nov. and emended description of the genus Catellibacterium
}

Correspondence

Wen-Jun Li

wjli@ynu.edu.cn

Jian $\mathrm{He}$

hejian@njau.edu.cn

\author{
Jin-Wei Zheng, ${ }^{1} \dagger$ Yi-Guang Chen, ${ }^{2,3}$ † Jun Zhang, ${ }^{1}$ Ying-Ying Ni, ${ }^{1}$ \\ Wen-Jun $\mathrm{Li}^{2,4}$ Jian $\mathrm{He}^{1}$ and Shun-Peng $\mathrm{Li}^{1}$ \\ ${ }^{1}$ Key Laboratory for Microbiological Engineering of Agricultural Environment of Ministry of \\ Agriculture, Nanjing Agricultural University, Nanjing 210095, PR China \\ ${ }^{2}$ Key Laboratory of Microbial Diversity in Southwest China Ministry of Education, Yunnan Institute of \\ Microbiology, Yunnan University, Kunming 650091, PR China \\ ${ }^{3}$ College of Biology and Environmental Science, Jishou University, Jishou 416000, PR China \\ ${ }^{4}$ Guangdong Key Laboratory of Marine Materia Medica, South China Sea Institute of Oceanology, \\ Chinese Academy of Sciences, Guangzhou 510301, PR China
}

The genus Catellibacterium, belonging to the family Rhodobacteraceae, was first proposed by Tanaka et al. (2004) with the description of Catellibacterium nectariphilum. Recently, a second species, Catellibacterium aquatile, was proposed by Liu et al. (2010), with an emended description of

†These authors contributed equally to this work.

The GenBank/EMBL/DDBJ accession number for the 16S rRNA gene sequence of strain DCA-1 ${ }^{\top}$ is FJ386516.

Three supplementary figures are available with the online version of this paper. the genus. During an investigation of the microbial diversity of a butachlor [ $N$-(butoxymethyl)-2-chloro- $N$-(2,6-diethylphenyl)acetamide] wastewater treatment facility in Jiangsu Province, China, a butachlor-degrading, Gram-negative bacterium, designated strain $\mathrm{DAC}-\mathrm{1}^{\mathrm{T}}$, was isolated from activated sludge. Based on the results of a polyphasic taxonomic study, this strain is considered to represent a novel species of the genus Catellibacterium.

Strain DCA- $1^{\mathrm{T}}$ was isolated from an activated sludge sample by plating $1: 10$ serial dilutions of the sample on LuriaBertani (LB) agar (Atlas \& Parks, 1993) supplemented with 
$100 \mathrm{mg}$ butachlor $\mathrm{l}^{-1}$ at $30{ }^{\circ} \mathrm{C}$ for 5 days. After primary isolation, the strain was purified by repeated streaking and subculturing (four or five times) on LB agar plates and examining the cultures by light microscopy. The isolate was preserved both on LB agar slants at $4{ }^{\circ} \mathrm{C}$ and as $20 \%(\mathrm{v} / \mathrm{v})$ glycerol stocks at $-80{ }^{\circ} \mathrm{C}$. Three reference strains, C. aquatile A1-9 ${ }^{\mathrm{T}}$, C. nectariphilum JCM $11959^{\mathrm{T}}$ and Rhodobacter changlensis JCM $14338^{\mathrm{T}}$, which were employed as controls in phenotypic tests (including chemotaxonomic studies), were obtained from the Institute of Microbiology, Chinese Academic Sciences (Beijing, China), and the Japan Collection of Microorganisms (Wako, Saitama, Japan). Unless indicated otherwise, morphological, physiological, biochemical, molecular and chemotaxonomic studies were performed with cells grown on $\mathrm{LB} / 10$ agar ( $1.0 \mathrm{~g}$ tryptone, $0.5 \mathrm{~g}$ yeast extract, $1.0 \mathrm{~g} \mathrm{NaCl}$ and $\left.15 \mathrm{~g}_{\text {agar }} \mathrm{l}^{-1}, \mathrm{pH} 7.0\right)$ at $30^{\circ} \mathrm{C}$.

Cell morphology was examined by using light microscopy (BH-2; Olympus) and transmission electron microscopy (JEOL; Japan). Internal membrane structures were viewed with a transmission electron microscope after the cells had been processed as described by Hanada et al. (2002). Gram staining and the $\mathrm{KOH}$ lysis test were carried out according to Smibert \& Krieg (1994) and Gregersen (1978), respectively. Growth was tested at $4{ }^{\circ} \mathrm{C}$ and at $5-50{ }^{\circ} \mathrm{C}$ (in increments of $5{ }^{\circ} \mathrm{C}$ ) and at $\mathrm{pH} 5.0-11.0$ (in increments of $0.5 \mathrm{pH}$ units) on LB/10 agar as well as in LB/10 medium. Tolerance of $\mathrm{NaCl}$ was tested on $\mathrm{LB} / 10$ agar as well as in $\mathrm{LB} / 10$ medium at $0-8 \%(\mathrm{w} / \mathrm{v}) \mathrm{NaCl}$ (in increments of $0.5 \%)$. Indole production and the Voges-Proskauer test were assessed as described by Smibert \& Krieg (1994). Decomposition of starch, Tweens 20 and 80 and tyrosine was determined as described by Cowan \& Steel (1965). Nitrate reduction was determined as described by Lányí (1987). Utilization of various carbon compounds was tested in a minimal medium [per litre deionized water: $1 \mathrm{~g}$ $\left(\mathrm{NH}_{4}\right)_{2} \mathrm{SO}_{4}, 0.05 \mathrm{~g}$ yeast extract, $0.5 \mathrm{~g} \mathrm{KH}_{2} \mathrm{PO}_{4}, 0.4 \mathrm{~g}$ $\mathrm{MgSO}_{4} \cdot 7 \mathrm{H}_{2} \mathrm{O}, 0.4 \mathrm{~g} \mathrm{NaCl}, 0.075 \mathrm{~g} \mathrm{CaCl}_{2} .2 \mathrm{H}_{2} \mathrm{O}, 5 \mathrm{ml}$ $0.1 \%$ ferric citrate solution, $1 \mathrm{ml}$ trace element solution (per litre deionized water: $0.1 \mathrm{~g} \mathrm{ZnSO}_{4} .7 \mathrm{H}_{2} \mathrm{O}, 0.03 \mathrm{~g}$ $\mathrm{MnCl}_{2} .4 \mathrm{H}_{2} \mathrm{O}, 0.3 \mathrm{~g} \mathrm{H}_{3} \mathrm{BO}_{4}, 0.2 \mathrm{~g} \mathrm{CoCl}_{2} .6 \mathrm{H}_{2} \mathrm{O}, 0.01 \mathrm{~g}$ $\mathrm{CuCl}_{2} \cdot 2 \mathrm{H}_{2} \mathrm{O}, 0.02 \mathrm{~g} \quad \mathrm{NiCl}_{2} \cdot 6 \mathrm{H}_{2} \mathrm{O}, 0.03 \mathrm{~g} \quad \mathrm{Na}_{2} \mathrm{MoO}_{4}$. $\left.2 \mathrm{H}_{2} \mathrm{O}\right)$ ]. Carbon sources were added at a final concentration of $4.0 \mathrm{~g} \mathrm{l}^{-1}$. Growth was examined by measuring the turbidity of cultures incubated at $30^{\circ} \mathrm{C}$ in $150 \mathrm{ml}$ Erlenmeyer flasks containing $40 \mathrm{ml}$ medium. Growth under anaerobic conditions was determined on LB agar supplemented with $0.5 \%(\mathrm{w} / \mathrm{v})$ glucose with or without $0.1 \%(\mathrm{w} / \mathrm{v})$ nitrate by using the GasPak Anaerobic System (BBL) according to the manufacturer's instructions. Phototrophic growth was assessed in minimal medium in completely filled screw-capped bottles under incandescent illumination (2000 lx); sodium succinate, sodium malate, sodium pyruvate, sodium citrate and glucose $\left(4.0 \mathrm{~g} \mathrm{l}^{-1}\right)$ were added as electron donors. The ability of the strain to degrade butachlor was determined according to the methods described by Chakraborty \& Bhattacharyya (1991). In vivo pigment-absorption spectrum analysis was examined as described by Yoon et al. (2004) using a UV-Vis spectrophotometer (UV-2450; Shimadzu). Observation of motility and tests of catalase and oxidase activities were conducted as described previously (Chen et al., 2007). Other enzyme activities and physiological and biochemical tests were also conducted by using API ZYM and API 20NE strips (bioMérieux) according to the manufacturer's instructions.

Strain DCA- $1^{\mathrm{T}}$ was strictly aerobic and the cells were Gramnegative, non-motile, non-sporulating rods (Supplementary Fig. S1, available in IJSEM Online). Colonies were pale yellow, convex and circular with entire margins. The strain grew in presence of $0-6 \%(\mathrm{w} / \mathrm{v}) \mathrm{NaCl}$ (optimum $1 \%)$, at 15-35 ${ }^{\circ} \mathrm{C}$ (optimum $25-30{ }^{\circ} \mathrm{C}$ ) and at $\mathrm{pH}$ 5.5-9.0 (optimum $\mathrm{pH}$ 7.0). Photoheterotrophic growth was not observed. Vesicular internal membrane structures and photosynthetic pigments were not detected (Supplementary Fig. S1). Strain DCA $-1^{\mathrm{T}}$ was able to degrade about $85 \%$ of $100 \mathrm{mg}$ butachlor $1^{-1}$ initially added to the minimal medium within 5 days (Supplementary Fig. S2). Detailed morphological, physiological and biochemical characteristics of strain DCA $-1^{\mathrm{T}}$ are summarized in the species description and in Table 1.

The 16S rRNA gene sequence was amplified by PCR and sequenced as described by Cui et al. (2001). Pairwise sequence similarity was calculated by using a global alignment algorithm, implemented at the EzTaxon server (Chun et al., 2007). Phylogenetic analysis was performed by using the software package MEGA version 4.1 (Tamura et al., 2007) after multiple alignment of the sequence data with CLUSTAL_X (Thompson et al., 1997). Distances were calculated by using distance options according to Kimura's two-parameter model (Kimura, 1980) and clustering was performed with the neighbour-joining method (Saitou \& Nei, 1987). Maximum-likelihood (Felsenstein, 1981) and maximum-parsimony (Kluge \& Farris, 1969) trees were generated by using the treeing algorithms contained in the PHYLIP package (Felsenstein, 2002). Confidence values for the branches of phylogenetic trees were determined by using bootstrap analyses (based on 1000 resamplings) (Felsenstein, 1985).

An almost-complete 16S rRNA gene sequence (1435 nt) was determined. Phylogenetic analysis based on $16 \mathrm{~S}$ rRNA gene sequences revealed that strain DCA- $1^{\mathrm{T}}$ was a member of the family Rhodobacteraceae and was related most closely to the type strain of $C$. aquatile $(96.5 \%$ sequence similarity); less than $95.5 \% 16 \mathrm{~S}$ rRNA gene sequence similarity was observed with other species of the Rhodobacteraceae. In the neighbour-joining phylogenetic tree, strain DCA- $1^{\mathrm{T}}$ formed a separate lineage with the type strains of $C$. aquatile, $R$. changlensis (95.4\%; Anil Kumar et al., 2007) and C. nectariphilum (94.3\%) (Fig. 1). Moreover, $R$. changlensis was also robustly included in the clade formed by the type strains of Catellibacterium species. The topology was similar to those of phylogenetic trees reconstructed by using the maximum-likelihood and maximum-parsimony methods (Supplementary Fig. S3). 
Table 1. Phenotypic characteristics that differentiate strain $D C A-1^{\top}$ from closely related type strains

Strain: 1, DCA $-1^{\mathrm{T}}$ (Catellibacterium caeni sp. nov.); 2, C. aquatile A1-9 ${ }^{\mathrm{T}}$; 3, C. nectariphilum JCM 11959 ${ }^{\mathrm{T}}$; 4, [R.] changlensis JCM 14338 ${ }^{\mathrm{T}}$ (Catellibacterium changlense comb. nov.). All data were obtained in this study. All strains are non-sporulating, non-motile and Gram-negative and are positive for activity of catalase, esterase (C4), esterase lipase (C8), leucine arylamidase and oxidase, but negative for anaerobiosis, indole production, fermentation of glucose, hydrolysis of gelatin, nitrate reduction, activity of $N$-acetyl- $\beta$-glucosaminidase, arginine dihydrolase, cystine arylamidase, $\alpha$-fucosidase, $\alpha$-galactosidase, $\beta$-galactosidase ( $p$-nitrophenyl- $\beta$-D-galactopyranosidase), $\beta$-glucuronidase, lipase (C14), $\alpha$-mannosidase and trypsin and utilization of benzoate, xylose, trehalose and phenylacetic acid.

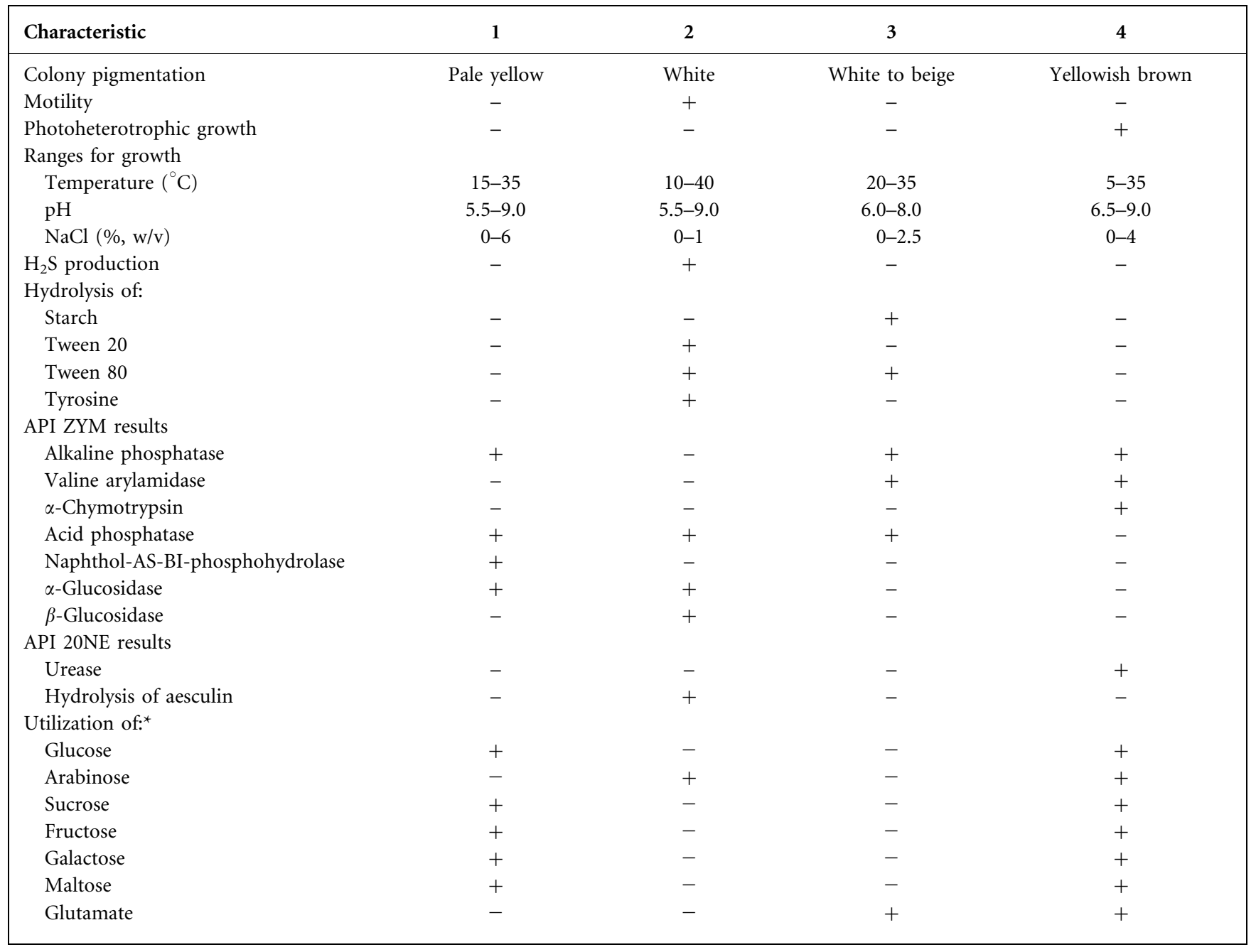

${ }^{\star}$ Utilization of various carbon sources was tested in minimal medium with each carbon source added at a final concentration of $4.0 \mathrm{~g} 1^{-1}$.

Therefore, it would appear that, on the basis of the phylogenetic data, strain $D C A-1^{\mathrm{T}}$ represents a novel species of the genus Catellibacterium according to accepted criteria (Stackebrandt \& Goebel, 1994), and that $R$. changlensis is highly related to the genus Catellibacterium.

DNA was isolated according to the method of Hopwood et al. (1985) and the $\mathrm{G}+\mathrm{C}$ content was determined by using the thermal denaturation method (Mandel \& Marmur, 1968). Analysis of respiratory quinones was carried out by the Identification Service of the DSMZ and Dr Brian Tindall (DSMZ, Braunschweig, Germany). Fatty acids were determined as described by Sasser (1990) using the Microbial Identification System (MIDI; Microbial ID).

The chemotaxonomic data obtained for strain DCA-1 ${ }^{\mathrm{T}}$ were consistent with the assignment of the strain to the genus Catellibacterium (Tanaka et al., 2004; Liu et al., 2010). The DNA G $+C$ content of strain DCA- $1^{T}$ was $62.5 \mathrm{~mol} \%$. The strain contained ubiquinone 10 (Q-10) $(87.4 \%)$ as the predominant respiratory quinone. The fatty acid profile of strain DCA- ${ }^{\mathrm{T}}$ was similar to those of the type strains of the two Catellibacterium species and $R$. changlensis, although there were differences in the proportions of some components (Table 2). The major fatty acids 


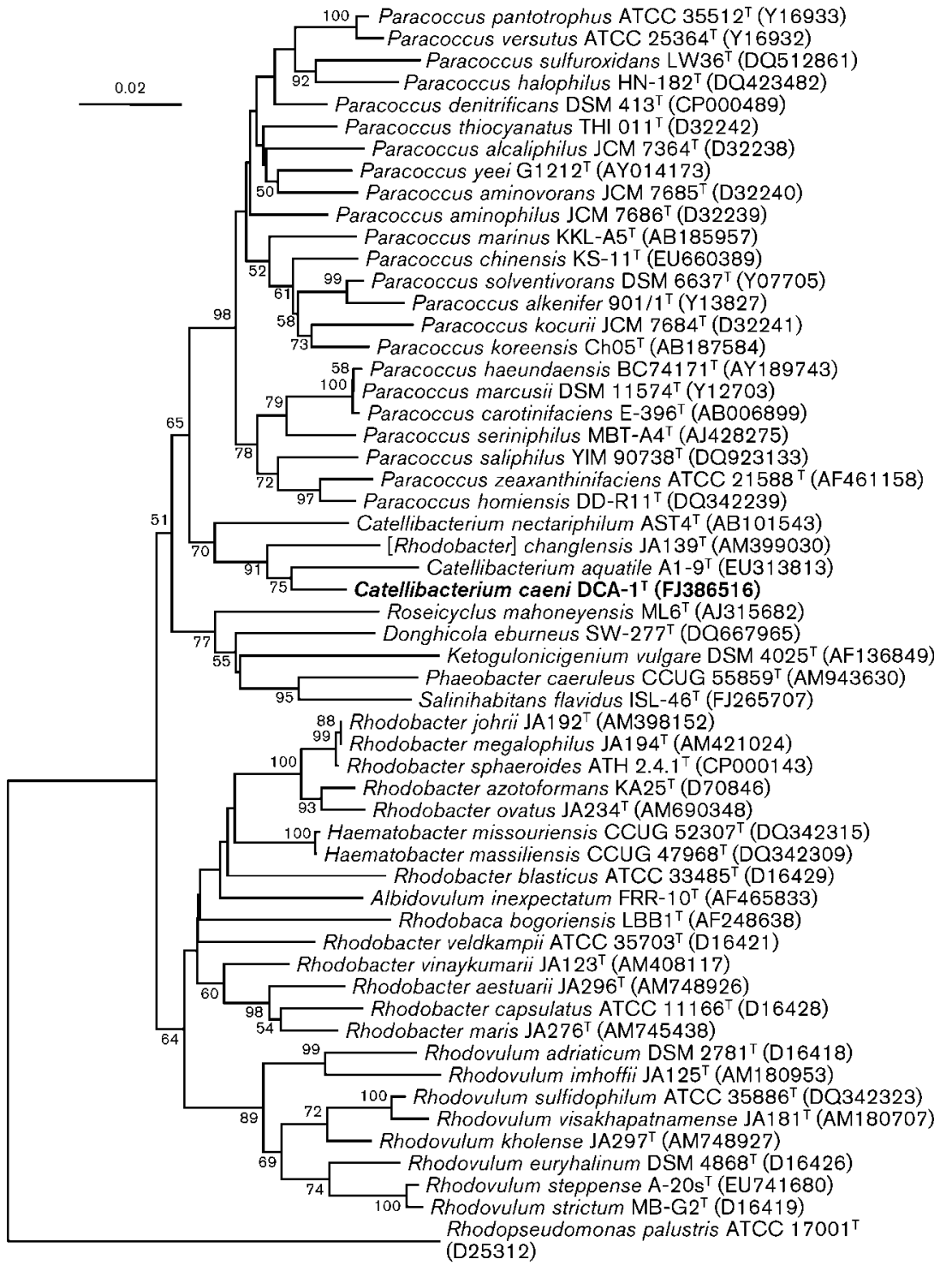

Fig. 1. Phylogenetic tree showing the position of strain DCA $-1^{\top}$ among related taxa based on 16S rRNA gene sequences reconstructed by using the neighbour-joining method. Numbers at nodes are bootstrap percentages (>50\%) based on a neighbour-joining analysis of 1000 resampled datasets. Bar, 2 substitutions per 100 nucleotide positions. $\left(>10 \%\right.$ of the total) of strain DCA- $1^{\mathrm{T}}$ were $\mathrm{C}_{18: 1} \omega 7 c$ $(67.7 \%)$ and 11-methyl $\mathrm{C}_{18: 1} \omega 7 c(13.3 \%)$.

On the basis of the results of the phylogenetic analysis and of morphological and chemotaxonomic investigations, strain DCA- $1^{\mathrm{T}}$ represents a novel species of the genus Catellibacterium, for which the name Catellibacterium caeni sp. nov. is proposed.

Rhodobacter changlensis was proposed by Anil Kumar et al. (2007) based on the fact that the type strain had some characteristics typical of genus Rhodobacter, such as the presence of intracytoplasmic membrane structures and carotenoids and phototrophic growth, but there was strong evidence from our phylogenetic analysis that $R$. changlensis was highly related to members of the genus Catellibacterium and was clearly separated from other members of the genus Rhodobacter in phylogenetic trees (three tree-making methods). Additionally, the fatty acid profile and DNA G $+\mathrm{C}$ content of
R. changlensis $\mathrm{JCM} 14338^{\mathrm{T}}$ were similar to those of the type strains of the two Catellibacterium species and strain DCA- $1^{\mathrm{T}}$. Accordingly, it is also proposed that Rhodobacter changlensis should be reclassified as Catellibacterium changlense comb. nov. This proposal necessitates an emended description of the genus Catellibacterium.

\section{Description of Catellibacterium caeni sp. nov.}

Catellibacterium caeni (cae'ni. L. gen. n. caeni of sludge).

Cells are non-sporulating, non-motile, catalase- and oxidase-positive, strictly aerobic, Gram-negative rods, approximately $0.6-0.7 \mu \mathrm{m}$ wide and $1.8-4.5 \mu \mathrm{m}$ long. Colonies are pale yellow-pigmented, convex and nontranslucent with circular margins, $1-2 \mathrm{~mm}$ in diameter after incubation on $\mathrm{LB} / 10$ agar at $30{ }^{\circ} \mathrm{C}$ for $2-3$ days. No diffusible pigments are produced. Growth occurs in $0-6 \%$ $(\mathrm{w} / \mathrm{v}) \mathrm{NaCl}$ (optimum, 1\%) at $\mathrm{pH}$ 5.5-9.0 (optimum, 
Table 2. Cellular fatty acid contents of strain $D C A-1^{\top}$ and closely related type strains

Strain: 1, DCA $-1^{\mathrm{T}}$ (C. caeni sp. nov.); 2, C. aquatile A1-9 3, C. nectariphilum JCM $11959^{\mathrm{T}} ; 4$, [R.] changlensis JCM $14338^{\mathrm{T}}$ (C. changlense comb. nov.). Data are percentages of total fatty acids. Fatty acids that represented $<1.0 \%$ for all strains are omitted. -, Not detected.

\begin{tabular}{|lcccc|}
\hline Fatty acid & $\mathbf{1}$ & $\mathbf{2}$ & $\mathbf{3}$ & $\mathbf{4}$ \\
\hline $\mathrm{C}_{10: 0} 3-\mathrm{OH}$ & 5.3 & - & 3.0 & 4.5 \\
$\mathrm{C}_{14: 0}$ & 0.2 & 2.0 & 0.8 & 0.4 \\
$\mathrm{C}_{16: 0}$ & 1.3 & 15.8 & 6.8 & 1.2 \\
$\mathrm{C}_{16: 0} 2-\mathrm{OH}$ & 0.2 & 4.5 & 1.5 & 0.2 \\
$\mathrm{C}_{17: 0}$ & 0.1 & 1.0 & 2.4 & 0.5 \\
$\mathrm{C}_{18: 0}$ & 1.9 & 16.7 & 9.1 & 3.4 \\
$\mathrm{C}_{18: 1} \omega 7 c$ & 67.7 & 49.0 & 57.2 & 71.4 \\
$\mathrm{C}_{18: 1} \omega 9 c$ & - & 3.7 & 1.6 & - \\
$11-$ Methyl $\mathrm{C}_{18: 1} \omega 7 c$ & 13.3 & 5.7 & 1.3 & 1.3 \\
$\mathrm{C}_{18: 0} 3-\mathrm{OH}$ & 2.1 & 0.8 & 2.9 & 0.1 \\
$\mathrm{C}_{19: 0}$ cyclo $\omega 8 c$ & - & - & 9.9 & - \\
$10-$ Methyl $\mathrm{C}_{19: 0}$ & 1.8 & - & 0.7 & 0.5 \\
Summed feature $3^{*}$ & 3.1 & - & 0.7 & 7.0 \\
Summed feature $7^{*}$ & 2.0 & - & 1.3 & 6.1 \\
\end{tabular}

*Summed features represent groups of two or three fatty acids that could not be separated by GLC with the MIDI system. Summed feature 3 contained $\mathrm{C}_{16: 1} \omega 7 c$ and/or $\mathrm{C}_{16: 1} \omega 6 c$. Summed feature 7 contained unknown ECL 18.846 and/or $\mathrm{C}_{19: 1} \omega 6 c$.

$\mathrm{pH}$ 7.0) and $15-35{ }^{\circ} \mathrm{C}$ (optimum, $25-30{ }^{\circ} \mathrm{C}$ ). Vesicular internal membrane structures and photosynthetic pigments are not present. Photoheterotrophic growth is not observed. Negative for urease activity, nitrate reduction, indole and $\mathrm{H}_{2} \mathrm{~S}$ production and decomposition of starch, Tweens 20 and 80 and tyrosine. The following compounds are utilized as carbon sources: fructose, D-galactose, glucose, maltose, sucrose, 2,3butanediol, glycerol, methanol, D-sorbitol, propionic acid, acetate, citrate, formate, malate, pyruvate and succinate. The following substances are not utilized: L-arabinose, lactose, trehalose, xylose, glutamate, adonitol, D-mannitol, D-ribose, benzoate and phenylacetic acid. Major fatty acids $(>10 \%$ of the total) are $\mathrm{C}_{18: 1} \omega 7 c$ and 11-methyl $\mathrm{C}_{18: 1} \omega 7 c$. The major isoprenoid quinone is Q-10. The DNA G+C content of the type strain is $62.5 \mathrm{~mol} \%$. Additional physiological, biochemical and chemotaxonomic properties are listed in Tables 1 and 2.

The type strain, DCA- $1^{\mathrm{T}}$ (=CGMCC $1.7745^{\mathrm{T}}=\mathrm{DSM}$ $\left.21823^{\mathrm{T}}\right)$, was isolated from activated sludge in a butachlor wastewater treatment facility in Jiangsu Province, China.

\section{Description of Catellibacterium changlense Anil Kumar et al. 2007 comb. nov.}

Catellibacterium changlense (chang.len'se. N.L. neut. adj. changlense of or pertaining to Changla Pass, the location from where the type strain was isolated).

Basonym: Rhodobacter changlensis Anil Kumar et al. 2007.
The description is the same as that given for Rhodobacter changlensis by Anil Kumar et al. (2007) with some changes listed in Tables 1 and 2 . The type strain is JA139 ${ }^{\mathrm{T}}(=\mathrm{DSM}$ $18774^{\mathrm{T}}=$ CCUG $53722^{\mathrm{T}}=$ JCM $14338^{\mathrm{T}}$ ).

\section{Emended description of the genus Catellibacterium Tanaka et al. 2005 emend. Liu et al. 2010}

The formal description as given by Tanaka et al. (2004) and emended by Liu et al. (2010) remains correct except that some species are photoheterotrophic.

\section{Acknowledgements}

We are grateful to Dr Susanne Verbarg and Dr B. J. Tindall (DSMZ) for the analysis of quinones, Mr Zheng Liu-Qiang for technical support and Dr Z.-P. Liu for providing the type strain C. aquatile A1 $-9^{\mathrm{T}}$. This work was supported by the National High Technology Research and Development Program of China (2006AA10Z402), the National Basic Research Program of China (no. 2010CB833800), the Natural Science Foundation of Jiangsu Province, China (BK2008331), and the Chinese National Technology Platform Programs (2005DKA21201-2).

\section{References}

Anil Kumar, P., Srinivas, T. N. R., Sasikala, Ch. \& Ramana, Ch. V. (2007). Rhodobacter changlensis sp. nov., a psychrotolerant, phototrophic alphaproteobacterium from the Himalayas of India. Int J Syst Evol Microbiol 57, 2568-2571.

Atlas, R. M. \& Parks, L. C. (1993). Handbook of Microbiological Media. Edited by L. C. Parks. Boca Raton, FL: CRC Press.

Chakraborty, S. K. \& Bhattacharyya, A. (1991). Degradation of butachlor by two soil fungi. Chemosphere 23, 99-105.

Chen, Y.-G., Cui, X.-L., Pukall, R., Li, H.-M., Yang, Y.-L., Xu, L.-H., Wen, M.-L., Peng, Q. \& Jiang, C.-L. (2007). Salinicoccus kunmingensis sp. nov., a moderately halophilic bacterium isolated from a salt mine in Yunnan, south-west China. Int J Syst Evol Microbiol 57, 2327-2332.

Chun, J., Lee, J.-H., Jung, Y., Kim, M., Kim, S., Kim, B. K. \& Lim, Y. W. (2007). EzTaxon: a web-based tool for the identification of prokaryotes based on $16 \mathrm{~S}$ ribosomal RNA gene sequences. Int J Syst Evol Microbiol 57, 2259-2261.

Cowan, S. T. \& Steel, K. J. (1965). Manual for the Identification of Medical Bacteria. London: Cambridge University Press.

Cui, X.-L., Mao, P.-H., Zeng, M., Li, W.-J., Zhang, L.-P., Xu, L.-H. \& Jiang, C.-L. (2001). Streptimonospora salina gen. nov., sp. nov., a new member of the family Nocardiopsaceae. Int J Syst Evol Microbiol 51, 357-363.

Felsenstein, J. (1981). Evolutionary trees from DNA sequences: a maximum likelihood approach. J Mol Evol 17, 368-376.

Felsenstein, J. (1985). Confidence limits on phylogenies: an approach using the bootstrap. Evolution 39, 783-791.

Felsenstein, J. (2002). PHYLIP (phylogeny inference package), version 3.6a. Distributed by the author. Department of Genome Sciences, University of Washington, Seattle, USA.

Gregersen, T. (1978). Rapid method for distinction of Gram-negative from Gram-positive bacteria. Eur J Appl Microbiol Biotechnol 5, 123-127.

Hanada, S., Takaichi, S., Matsuura, K. \& Nakamura, K. (2002). Roseiflexus castenholzii gen. nov., sp. nov., a thermophilic, filamentous, photosynthetic bacterium that lacks chlorosomes. Int J Syst Evol Microbiol 52, 187-193. 
Hopwood, D. A., Bibb, M. J., Chater, K. F., Kieser, T., Bruton, C. J., Kieser, H. M., Lydiate, D. J., Smith, C. P. \& Ward, J. M. (1985). Genetic Manipulation of Streptomyces: a Laboratory Manual. Norwich: John Innes Foundation.

Kimura, M. (1980). A simple method for estimating evolutionary rates of base substitutions through comparative studies of nucleotide sequences. J Mol Evol 16, 111-120.

Kluge, A. G. \& Farris, F. S. (1969). Quantitative phyletics and the evolution of anurans. Syst Zool 18, 1-32.

Lányí, B. (1987). Classical and rapid identification methods for medically important bacteria. Methods Microbiol 19, 1-67.

Liu, Y., Xu, C.-J., Jiang, J.-T., Liu, Y.-H., Song, X.-F., Li, H. \& Liu, Z.-P. (2010). Catellibacterium aquatile sp. nov., isolated from freshwater and emended description of the genus Catellibacterium Tanaka et al. 2004. Int J Syst Evol Microbiol 60, 2027-2031.

Mandel, M. \& Marmur, J. (1968). Use of ultraviolet absorbancetemperature profile for determining the guanine plus cytosine content of DNA. Methods Enzymol 12B, 195-206.

Saitou, N. \& Nei, M. (1987). The neighbor-joining method: a new method for reconstructing phylogenetic trees. Mol Biol Evol 4, 406-425.

Sasser, M. (1990). Identification of bacteria by gas chromatography of cellular fatty acids. MIDI Technical Note 101. Newark, DE: MIDI, Inc.
Smibert, R. M. \& Krieg, N. R. (1994). Phenotypic characterization. In Methods for General and Molecular Bacteriology, pp. 607-654. Edited by P. Gerhardt, R. G. E. Murray, W. A. Wood \& N. R. Krieg. Washington, DC: American Society for Microbiology.

Stackebrandt, E. \& Goebel, B. M. (1994). Taxonomic note: a place for DNA-DNA reassociation and $16 \mathrm{~S}$ rRNA sequence analysis in the present species definition in bacteriology. Int J Syst Bacteriol 44, 846-849.

Tamura, K., Dudley, J., Nei, M. \& Kumar, S. (2007). MEGA4: molecular evolutionary genetic analysis (MEGA) software version 4.0. Mol Biol Evol 24, 1596-1599.

Tanaka, Y., Hanada, S., Manome, A., Tsuchida, T., Kurane, R., Nakamura, K. \& Kamagata, Y. (2004). Catellibacterium nectariphilum gen. nov., sp. nov., which requires a diffusible compound from a strain related to the genus Sphingomonas for vigorous growth. Int $J$ Syst Evol Microbiol 54, 955-959.

Thompson, J. D., Gibson, T. J., Plewniak, F., Jeanmougin, F. \& Higgins, D. G. (1997). The CLUSTAL_X windows interface: flexible strategies for multiple sequence alignment aided by quality analysis tools. Nucleic Acids Res 25, 4876-4882.

Yoon, J.-H., Yeo, S.-H. \& Oh, T.-K. (2004). Hongiella marincola sp. nov., isolated from sea water of the East Sea in Korea. Int J Syst Evol Microbiol 54, 1845-1848. 